\title{
European Impatiens species differences at RAPD and ISSR loci
}

\section{Edita Ramonienè,}

\section{Lina Jociené,}

\section{Algimantas Paulauskas, \\ Eugenija Kupčinskienė ${ }^{\star}$}

Vytautas Magnus University, Vileikos 8, Kaunas, Lithuania
Information concerning comparison of three widely spread European species of Impatiens along wider geographical areas is still missing. The present study is aimed at comparing genetic variability at RAPD and ISSR loci of Impatiens noli-tangere, I. parviflo$r a$, and I. glandulifera, covering a marked geographic area. Twenty four populations of these Impatiens (eight populations of each species) from two countries (Lithuania and Czech Republic) were examined. Eight randomly amplified polymorphic DNA (RAPD) and 5 inter simple sequence repeat (ISSR) markers were chosen considering the lack of data on the general molecular characteristics of Impatiens. The highest genetic differentiation at RAPD loci $\left(G_{S T}=0.81\right)$ was characteristic of I. parviflora, and the highest genetic differentiation at ISSR loci $\left(G_{S T}=0.73\right)$ was documented for I. glandulifera. According to Nei's genetic distances between two species populations, significant correlations were determined for I. noli-tangere and I. parviflora $(r=0.79 ; p<0.05)$ and for I. parviflora and I. glandulifera $(r=0.76 ; p<0.05)$ based on RAPD loci and for I. parviflora and I. glandulifera $(r=0.89 ; p<0.05)$ based on ISSR loci. According to the mean values of polymorphism, genetic differentiation and Nei's genetic distances between two species populations at RAPD loci, the closest were I. noli-tangere and I. parviflora, while at ISSR loci, the most similar were invasive species, I. parviflora and I. glandulifera. UPGMA dendrograms revealed that the closest species were I. noli-tangere and I. parviflora by both RAPD and ISSR data. In conclusion, our study did not show unambiguous results about similarity between Impatiens species.

Key words: Balsaminaceae, balsams, alien species, genetic variability

\section{INTRODUCTION}

The touch-me-not balsam (Impatiens noli-tangere L.) is present as a native species in almost all European countries. This Impatiens species is

\footnotetext{
*Corresponding author. E-mail: e.kupcinskiene@gmail.com
}

found mainly in the temperate zone, that is why it is absent in Spain, Greece, and northern part of Scandinavia (Hatcher, 2003). It is naturally growing in many Asian countries, like Russia, Japan and Mongolia. In North America, I. nolitangere is present in regions from south Alaska 
to Washington State. Invasive areas of this species have not been described, with exception of one note that in some places of Great Britain it is alien (Hatcher, 2003). Such statement has no further support from other studies.

The small balsam (Impatiens parviflora DC) is native in Afghanistan, Kazakhstan, Turkmenistan, Uzbekistan, Tajikistan (Tanner, 2008). It is an invasive species across Europe, including northern countries of Scandinavia and southern countries near the Mediterranean Sea (Coombe, 1956); also it is an invader of North America, being documented for west Canada and almost all United States (Tanner, 2008).

The native region of the Himalayan balsam (Impatiens glandulifera Royle) is limited to a small area of Asia, covering a $40 \mathrm{~km}$ belt of the Himalays mountains belonging to four neighbouring countries (India, Pakistan, Nepal, and China) (Beerling, Perrins, 1993). In the remainder part of Asia and in other continents like North America, Australia and Europe, it is an invasive species documented for Russia, Canada (Clements, 2008), USA (Tanner, 2008), New Zealand, Central Europe to northern countries, Britain and Ireland (Beerling, Perrins, 1993).

Hereby, I. glandulifera and I. parviflora are characterized as invasive plants growing in most parts of Europe (Coombe, 1956; Helmisaari, 2010).

There are overlapping areas of I. noli-tangere, I. parviflora, and I. glandulifera in Europe and North America, so this fact may lead to a native I. noli-tangere colonization by alien species of the same genera.

Favourable conditions for invasion of these two alien Impatiens species are created by natural and mainly anthropogenic factors such as ground water level change and flooding of rivers (Csiszar, Bartha, 2008), destroyed vegetative cover (Dobravolskaité, 2012), neglected and unattended territories, destruction of forests, planting in gardens, and other favourable factors (Gudzinskas, 1998). A very important reason of invasion is the fact that an alien species may colonize new eroded places faster due to its better capabilities for adaptation. The small balsam could exist in areas which are too dry and shaded for I. noli-tangere, and I. glandulifera could survive in open light-demanding areas, which are not suitable for a native one (Čuda et al., 2014). There are some areas of coexistence of all three Impatiens species in Central Europe (Čuda et al., 2014). There are some habitats where both native and alien species can coexist naturally in the Eastern Baltic area (Kupcinskiene et al., 2015). These circumstances help indicate what differences are between invasive and native species (Vervoort, Jacquemart, 2012) and what specific characters are beneficial for invaders. I. parviflora and I. glandulifera are more adaptive to unfavourable environment conditions than I. noli-tangere (Godefroid, Koedam, 2010). Similarities of these territories led to an evolutionary plant adaptation to the local climate (Skalova et al., 2011) and might get reflection on the molecular level.

The randomly amplified polymorphic DNA (RAPD) and inter simple sequence repeat (ISSR) marker methods are applicable to many species of plants around the world (Nybom et al., 2014), because they are inexpensive and fast, do not require special information about the species; in addition, DNA loci cover various places of genome. Studies using these methods have been successfully conducted since 1990 (Williams et al., 1990). Nowadays, these methods are still widely used in comparing crop varieties or populations (Dabkevičienè et al., 2011; Yilmaz et al., 2012). Some investigations of invasive plants in Lithuania have been done by RAPD and ISSR markers: Bunias orientalis L. (Patamsyte et al., 2011), Lupinus polyphyllus Lindl. (Vyšniauskienè et al., 2011), Medicago sativa L. (Vyšniauskienè et al., 2013). The methods mentioned above are chosen considering the lack of data on the general molecular characteristics of Impatiens. As invasive Lithuania species, I. glandulifera (Zybartaite et al., 2011) or I. parviflora (Kupcinskiene et al., 2011; Kupcinskiene et al., 2015) populations were separately investigated by dominant markers, but information covering comparison of three Impatiens species along wider geographical areas is still missing. The wider the geographical area, the bigger differences might be expected 
concerning adaptation to the local climate and edaphic conditions. These differences might get reflection in DNA loci examined by RAPD and ISSR markers.

Interspecies studies are needed to check if the species might be separated employing some genetic markers. Interspecific interactions between balsam species are important to know when solving plant invasion problems. There are favourable conditions to compare Impatiens of a wider geographical region of Europe, because there are many places where three Impatiens species are growing beside or in close vicinity.

The present study is aimed at comparing genetic variability at RAPD and ISSR loci of three European species of Impatiens covering a marked geographic area.

\section{MATERIALS AND METHODS}

\section{Plant material}

I. noli-tangere, I. parviflora, and I. glandulifera were collected in 2012. Eight populations of each 3 Impatiens species growing beside or at a small distance were sampled in Lithuania (Anykščiai - Any, Varèna - Var, Kaunas - Kau, Juodkrantè - Juo) and in Czech Republic (Potstejn - Pot, Polabí, Velký Osek - Pol, Celina - Cel, Cernetice by Volyne - Vol). The population sampling included territories along $56^{\circ} 20^{\prime}-49^{\circ} 14^{\prime}$ latitude $(\mathrm{N})$ and $25^{\circ} 30^{\prime}-13^{\circ} 89^{\prime}$ longitude (E); location details are described earlier (Kupcinskiene et al., 2015). Each plant sample included the top of the shoot without any abiotic or biotic damage. Detached plant parts were transferred to the bags with silica gel. Top leaves were taken and cooled at $-20^{\circ} \mathrm{C}$ temperature in the laboratory of the Department of Biology (Vytautas Magnus University).

\section{DNA extraction, RAPD and ISSR analyses}

For DNA extraction, the DNA Purification Kit (\#KO512, Thermo Scientific, Lithuania) was used. To measure concentration and to determine purity of DNA, a spectrophotometer NanoDrop 2000 (Thermo Fisher Scientific, USA) was used. RAPD and ISSR primers were used as it was described earlier (Kupcinskiene et al., 2015). Markers employed were OP-A20, OPD20, 222, 250, 269, 340, 474, 516 (RAPD) and ISSR2, ISSR3, ISSR4, ISSR5, and ISSR6 (ISSR). For polymerase chain reaction, a thermo-cycler Mastercycler gradient (Eppendorf, Germany) was used. PCR products were realized in $1.5 \%$ agarose gel electrophoresis. RAPD data was collected based on Williams et al. (1990) method, with some modifications.

\section{Statistical analysis}

Electrophoresis images were analyzed using the GeneRulerTM $1 \mathrm{~kb}$ DNA Ladder Plus (Thermo Scientific, Lithuania) ruler. The presence (1) or absence (0) of DNA fragments of a particular fragment size was determined and a data sheet was composed.

DNA polymorphic loci $(P \%)$ were counted and analyzed using Genetic Analysis in Excel (GenAlEx) version 6.4. Genetic differentiation $\left(G_{S T}\right)$, genetic flow between populations $\left(N_{m}\right)$, and Nei's genetic distances (GD) were calculated with PopGene, version 1.32 (Nei, 1978). According to Nei's genetic distances (GD), populations were grouped into the clusters using an unweighted pair group method with arithmetic mean (UPGMA).

\section{RESULTS AND DISCUSSION}

The highest polymorphism $(P \%)$ for all three Impatiens species was documented at ISSR loci compared to RAPD loci or RAPD + ISSR loci (Fig. 1). According to the mean values (for all populations of each species) of this parameter at RAPD loci, the closest were I. noli-tangere and $I$. parviflora (mean $P \%=13.9 \%$ and $P \%=17.3 \%$, respectively). The minimum difference of average of polymorphic loci based on ISSR data was between I. parviflora and I. glandulifera (mean $P \%=26.5 \%$ and $P \%=22.0 \%$, respectively).

The greatest genetic differentiation according to RAPD markers was in I. parviflora populations $\left(G_{S T}=0.81\right)$ and the lowest in I. glandulifera populations $\left(G_{S T}=0.61\right.$; Table 1$)$. The results of gene flow between populations were opposite 

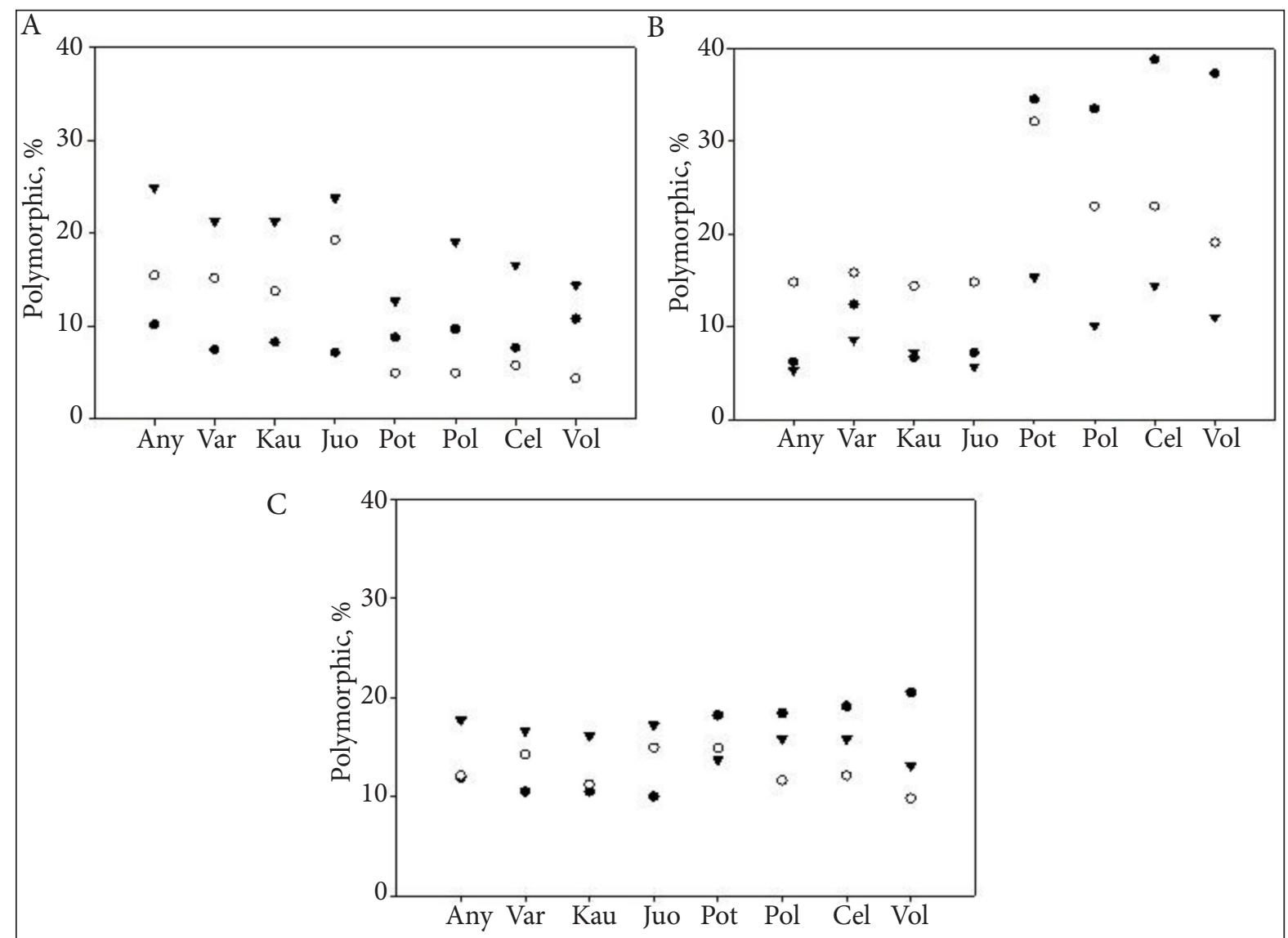

Fig. 1. Percentage of polymorphic loci (P\%) of three Impatiens species, each represented by eight populations. A - P\% at RAPD loci, B - P\% at ISSR loci, C - P\% at RAPD + ISSR loci, $\bullet-I$. noli-tangere, o - I. parviflora, $\boldsymbol{\nabla}$ - I. glandulifera. Any, Var, Kau, Juo, Pot, Pol, Cel, Vol - abbreviated titles of populations

Table 1. I. noli-tangere, I. parviflora, and I. glandulifera genetic differentiation $\left(G_{S T}\right)$ and genetic flow between populations $\left(N_{m}\right)$

\begin{tabular}{ccc}
\hline DNA marker type & $G_{S T}$ & $N_{m}$ \\
\hline \multicolumn{3}{c}{ I. noli-tangere } \\
\hline RAPD & 0.79 & 0.13 \\
\hline ISSR & 0.36 \\
\hline \multicolumn{3}{c}{ I. parviflora } \\
\hline RAPD & 0.81 \\
\hline ISSR & 0.68 \\
\hline \multicolumn{3}{c}{0.12} \\
\hline RAPD & 0.23 \\
\hline ISSR & 0.61 \\
\hline
\end{tabular}

to genetic differentiation: the lowest value was for I. parviflora $\left(N_{m}=0.12\right)$, while the highest for I. glandulifera $\left(N_{m}=0.32\right)$. According to
ISSR markers data, the highest genetic differentiation $\left(G_{S T}=0.73\right)$ and the lowest gene flow $\left(N_{m}=0.18\right)$ were visible between I. glandulifera populations. However, the lowest genetic differentiation was in I. noli-tangere populations $\left(G_{S T}=0.36\right)$, where gene flow was the highest $\left(N_{m}=0.89\right)$. To sum up these results, I. nolitangere and I. parviflora were similar species at RAPD loci, while invasive balsams were similar at the ISSR markers. There is evidence to argue about genetic differentiation importance for the invasion process in rapidly changing conditions (Bossdorf et al., 2005), and this is noticeable in our studies. Both invasive species, I. parviflora and I. glandulifera, had, respectively, the highest genetic differentiation at RAPD loci and the highest genetic differentiation at ISSR loci. This could cause these species' 
Table 2. Nei's genetic distances for populations of three Impatiens species at RAPD (lower triangle) loci and ISSR loci (upper triangle)

\begin{tabular}{|c|c|c|c|c|c|c|c|c|c|}
\hline \multirow{8}{*}{ 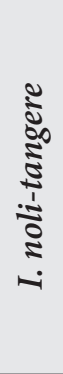 } & Any & $\mathrm{X}$ & 0.180 & 0.116 & 0.059 & 0.093 & 0.107 & 0.103 & 0.071 \\
\hline & Var & 0.368 & $\mathrm{X}$ & 0.125 & 0.165 & 0.144 & 0.123 & 0.140 & 0.115 \\
\hline & Kau & 0.295 & 0.299 & $\mathrm{X}$ & 0.062 & 0.097 & 0.110 & 0.094 & 0.104 \\
\hline & Juo & 0.334 & 0.250 & 0.303 & $X$ & 0.086 & 0.101 & 0.079 & 0.074 \\
\hline & Pot & 0.333 & 0.295 & 0.350 & 0.284 & $\mathrm{X}$ & 0.037 & 0.053 & 0.054 \\
\hline & Pol & 0.378 & 0.322 & 0.399 & 0.322 & 0.125 & $\mathrm{X}$ & 0.053 & 0.042 \\
\hline & Cel & 0.405 & 0.328 & 0.373 & 0.322 & 0.123 & 0.152 & $\mathrm{X}$ & 0.066 \\
\hline & Vol & 0.374 & 0.304 & 0.378 & 0.274 & 0.081 & 0.117 & 0.167 & $\mathrm{X}$ \\
\hline \multirow{8}{*}{ 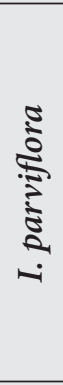 } & Any & $X$ & 0.166 & 0.190 & 0.157 & 0.348 & 0.348 & 0.338 & 0.388 \\
\hline & Var & 0.254 & $\mathrm{X}$ & 0.126 & 0.138 & 0.268 & 0.286 & 0.278 & 0.303 \\
\hline & Kau & 0.289 & 0.269 & $\mathrm{X}$ & 0.125 & 0.321 & 0.344 & 0.318 & 0.355 \\
\hline & Juo & 0.272 & 0.358 & 0.283 & $\mathrm{X}$ & 0.314 & 0.327 & 0.321 & 0.358 \\
\hline & Pot & 0.362 & 0.409 & 0.403 & 0.451 & $\mathrm{X}$ & 0.031 & 0.035 & 0.036 \\
\hline & Pol & 0.349 & 0.379 & 0.351 & 0.382 & 0.131 & $\mathrm{X}$ & 0.056 & 0.053 \\
\hline & Cel & 0.408 & 0.421 & 0.393 & 0.460 & 0.172 & 0.129 & $\mathrm{X}$ & 0.072 \\
\hline & Vol & 0.410 & 0.409 & 0.409 & 0.398 & 0.153 & 0.137 & 0.163 & $\mathrm{X}$ \\
\hline \multirow{9}{*}{ 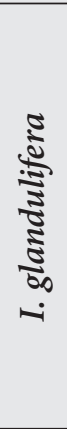 } & Any & $\mathrm{X}$ & 0.231 & 0.151 & 0.154 & 0.360 & 0.391 & 0.326 & 0.368 \\
\hline & Var & 0.162 & $\mathrm{X}$ & 0.176 & 0.244 & 0.420 & 0.438 & 0.373 & 0.419 \\
\hline & Kau & 0.122 & 0.148 & $\mathrm{X}$ & 0.171 & 0.339 & 0.364 & 0.309 & 0.374 \\
\hline & Juo & 0.150 & 0.198 & 0.132 & $\mathrm{X}$ & 0.463 & 0.499 & 0.425 & 0.445 \\
\hline & Pot & 0.291 & 0.314 & 0.292 & 0.316 & $\mathrm{X}$ & 0.140 & 0.128 & 0.093 \\
\hline & Pol & 0.275 & 0.309 & 0.254 & 0.294 & 0.159 & $X$ & 0.133 & 0.205 \\
\hline & Cel & 0.284 & 0.294 & 0.291 & 0.273 & 0.188 & 0.207 & $\mathrm{X}$ & 0.092 \\
\hline & Vol & 0.309 & 0.343 & 0.305 & 0.298 & 0.129 & 0.196 & 0.226 & $\mathrm{X}$ \\
\hline & & Any & Var & Kau & Juo & Pot & Pol & Cel & Vol \\
\hline
\end{tabular}

successful invasiveness in the studied areas of Europe. According to genetic differentiation, I. parviflora was in the intermediate position compared to all three Impatiens species.

The pairs of Impatiens species were compared according to correlations between population Nei's genetic distances defined for RAPD and ISSR loci. Nei's genetic distances at RAPD loci significantly correlated for I. noli-tangere and I. parviflora $(r=0.79 ; p<0.05)$ and for I. parviflora and I. glandulifera $(r=0.76$; $p<0.05)$; correlation was not observed in case of I. noli-tangere and I. glandulifera comparison $(r=0.49 ; p>0.05)$. Nei's genetic distances at ISSR loci significantly correlated for $I$. parviflora and I. glandulifera ( $r=0.89 ; p<0.05)$; correlation was not observed in case of $I$. nolitangere and I. parviflora comparison $(r=0.36$; $p>0.05)$ and for I. noli-tangere and I. glandulifera $(r=0.38$; $p>0.05)$. Relying on the men- tioned data, the highest correlations were between I. parviflora and I. glandulifera at ISSR loci. Our data suggested that among three pairs of Impatiens species, the paired I. parviflora and I. glandulifera (invasive species) were significantly the closest to each other according to correlations of Nei's genetic distances defined at ISSR loci.

According to the UPGMA dendrogram of genetic relations among populations of I. nolitangere and I. parviflora based on RAPD data, the species did not branch into different clades, either species separated similarly based on ISSR markers and RAPD + ISSR markers data (Fig. 2a). I. noli-tangere and I. glandulifera species population comparison UPGMA dendrograms based on RAPD, ISSR, and RAPD + ISSR data showed that species were clearly detached by the RAPD and ISSR markers, but were not by conjugated markers data (Fig. 2b). 


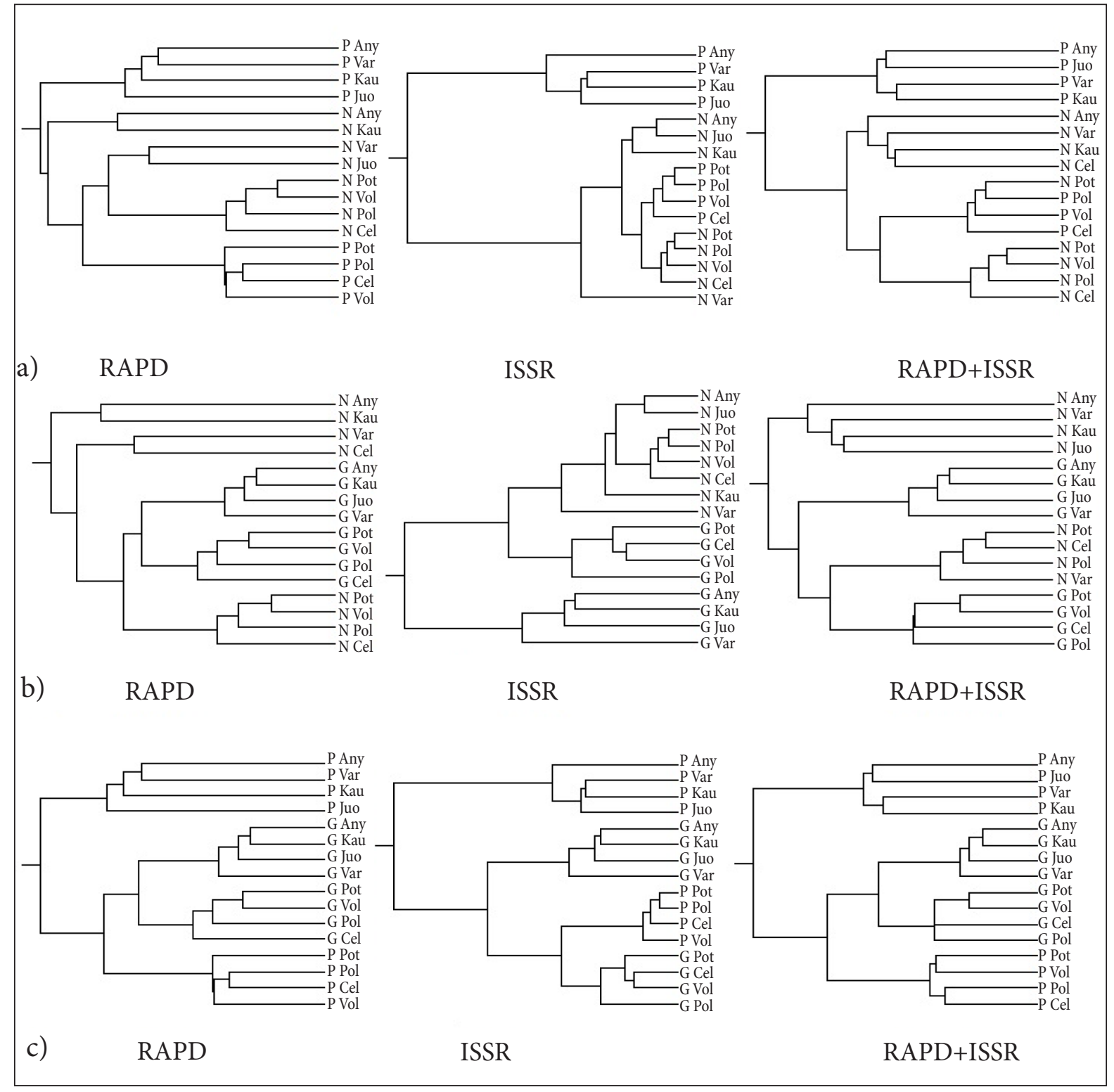

Fig. 2. UPGMA dendrograms of genetic relations among populations of I. noli-tangere, I. parviflora, and I. glandulifera (8 populations for each species) based on RAPD, ISSR, and RAPD + ISSR data, using UPGMA algorithm and Nei's genetic distances: a) - dendrograms of I. parviflora and I. noli-tangere, b) - dendrograms of I. glandulifera and I. noli-tangere, and c) - dendrograms of I. parviflora and I. glandulifera. In the dendrograms, the title of each population comprises species name ( $\mathrm{N}$ - I. noli-tangere, $\mathrm{P}$ - I. parviflora, G - I. glandulifera) and abbreviated titles of populations (Any, Var, Kau, Juo, Pot, Pol, Cel, Vol)

Nevertheless, we suggested segregating I. nolitangere and I. glandulifera as different species. UPGMA dendrograms based on RAPD, ISSR, and RAPD + ISSR markers revealed I. parviflora and I. glandulifera populations as distinct groups by RAPD data and by conjugated markers data, while ISSR markers data showed scattered populations (Fig. 2c).
The UPGMA dendrogram of genetic relations among populations of $I$. noli-tangere, I. parviflora, and I. glandulifera (8 populations for each species) based on RAPD data revealed I. glandulifera as the most distinct species, all populations of which formed separate clades, while I. noli-tangere and I. parviflora were scattered, I. parviflora in particular (Fig. 3). 


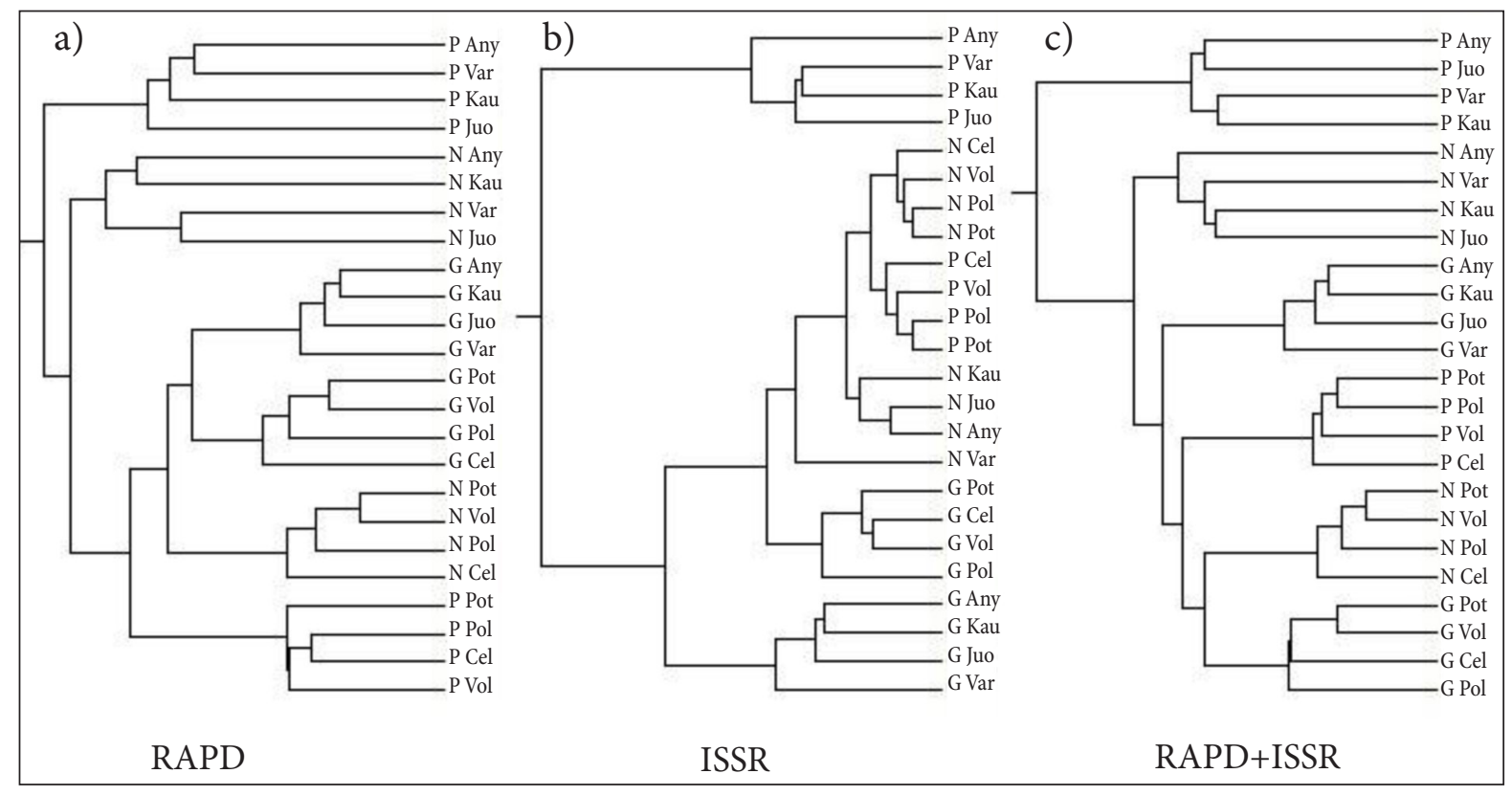

Fig. 3. UPGMA dendrograms of genetic relations among populations of I. noli-tangere, I. parviflora, and I. glandulifera (8 populations for each species) based on a) RAPD data, b) ISSR data, c) RAPD and ISSR data, using UPGMA algorithm and Nei's genetic distances. In the dendrograms the title of each population comprises species name ( $\mathrm{N}-$ I. noli-tangere, $\mathrm{P}-\mathrm{I}$. parviflora, $\mathrm{G}-\mathrm{I}$. glandulifera) and abbreviated titles of populations (Any, Var, Kau, Juo, Pot, Pol, Cel, Vol)

Similarly, the UPGMA dendrogram based on ISSR data revealed I. glandulifera as the most distinct species, the populations of which formed two related clades, and the populations of the other two Impatiens species did not behave in the same manner. For separation of Impatiens species, the UPGMA dendrogram based on combined RAPD and ISSR data was not helpful at all.

Our dendrograms based on RAPD or ISSR data for three Impatiens species showed bigger similarity between I. noli-tangere and I. parviflora: they did not form separate clades. This was also true when comparing the mean values of polymorphism at RAPD loci of these two species. It is in agreement with a bigger morphological similarity (height of the plant and size of the flowers) between $I$. noli-tangere and I. parviflora and indicatory values of their habitats (values for each factor ranging between 1 and 9; Ellenberg et al., 1992). I. noli-tangere and $I$. parviflora were determined as similar species by several features of their environ- ment: light demand (4), climate type (5), and nitrogen quantity in soil (6). I. glandulifera and I. parviflora were characterised as similar only in the requirement for soil reaction (7).

According to correlations between population Nei's genetic distances defined for ISSR loci, I. parviflora and I. glandulifera were more similar to each other, compared to the other pairs of Impatiens species. It is in support to phylogenetic similarity between I. glandulifera and I. parviflora according to phylogenetic trees of combined ITS and $a t p B-r b c L$ spacer data (Janssens et al., 2009).

Our study did not show unambiguous results. It might be due to the fact that selected RAPD and ISSR markers trigged Impatiens loci responsible for different features and functions. Balsaminaceae species, including three Impatiens species studied by us, were compared using DNA sequencing (Janssens et al., 2006; Janssens et al., 2009). Relations between three Impatiens species differed depending on the scope of loci selected for sequencing. In 
the phylogenetic tree based on atpB-rbcL spacer data (Janssens et al., 2006), I. noli-tangere, I. parviflora, and I. glandulifera were allocated in parallel clades.

Molecular markers are important to determine invasion pathways and genetic variation of introduced plants (Bossdorf et al., 2005). For further comparisons of three European species of Impatiens, extension of population geography and molecular markers is required.

\section{CONCLUSIONS}

1. The present study revealed that I. noli-tangere and I. parviflora were the most similar species by polymorphic loci $(P \%)$, genetic differentiation $\left(G_{S T}\right)$, UPGMA dendrograms based on RAPD and ISSR data, also based on RAPD data correlation between Nei's genetic distances among pairs of populations of these two species.

2. Among three pairs of Impatiens species, the paired I. parviflora and I. glandulifera (invasive species) were the closest to each other according to significant correlations of Nei's genetic distances defined at ISSR loci.

3. Our data suggested that I. noli-tangere and I. glandulifera were the most different species by almost all investigated parameters based on RAPD and ISSR markers.

\section{Acknowledgements}

This study was funded by the Research Council of Lithuania, grant No. LEK-07/2012. For the plant material from Czech Republic and valuable advice we are grateful to Dr. Hana Skalova and Prof. Petr Pyšek.

Received 6 January 2016

Accepted 6 March 2016

\section{References}

1. Beerling DJ, Perrins JM. Impatiens glandulifera Royle. J Ecol. 1993; 81(177): 367-82.

2. Bossdorf O, Auge H, Lafuma L, Rogers WE, Siemann E, Prati D. Phenotypic and genetic differentiation between native and introduced plant populations. Oecologia. 2005; 144: 1-11.

3. Clements DR, Feenstra KR, Jones K, Staniforth R. The biology of invasive alien plants in Canada. 9. Impatiens glandulifera Royle. Can J Plant Sci. 2008; 88: 403-17.

4. Coombe DE. Biological flora of the British Isles, Impatiens parviflora DC. J Ecol. 1956; 44(2): 701-13.

5. Csiszar A, Bartha D. Small balsam (Impatiens parviflora DC.). In: Botta-Dukat Z, Balogh L (ed.). The most important invasive plants in Hungary. Institute of Ecology and Botany, Hungarian Academy of Sciences, Vacratot, Hungary; 2008. p. 139-49.

6. Čuda J, Skalova H, Janovsky Z, Pyšek P. Habitat requirements, short-term population dynamics and coexistence of native and invasive Impatiens species: a field study. Biol Invasions. 2014; 16: 177-90.

7. Dabkevičienė G, Paplauskienė V, Vilčinskas E. Assessment of genetic diversity in Trifolium spp. using ISSR and RAPD markers. J Food Agric Environ. 2011; 9(1): 210-4.

8. Dobravolskaitè R. Alien species Impatiens parviflora invasion into forest communities of Lithuania. Bot Lith. 2012; 18(1): 3-12.

9. Ellenberg H, Ruprecht D, Volkmar W, Willy W, Dirk P. Zeigerwerte von Pflanzen in Mitteleuropa. Scripta Geobot. 1992; 18: 1-258. German.

10. Godefroid S, Koedam N. Comparative ecology and coexistence of introduced and native congeneric forest herbs: Impatiens parviflora and I. noli-tangere. Plant Ecol Evol. 2010; 143: 119-127.

11. Gudzinskas Z. Conspectus of alien plant species of Lithuania. 8. Aceraceae, Balsaminaceae, Elaeagnaceae, Geraniaceae, Hippocastanaceae, Linaceae, Lythraceae, Onagraceae, Oxalidaceae, Rutaceae, and Vitaceae. Bot Lith. 1998; 4: 363-77.

12. Hatcher PE. Biological flora of the British Isles, Impatiens noli-tangere L. J Ecol. 2003; 91: 147-67.

13. Helmisaari H. NOBANIS - Invasive alien species fact sheet - Impatiens glandulifera [Internet]. 
2010. Online database of the North European and Baltic Network on invasive alien species - NOBANIS. Available from: https:// www.nobanis.org/globalassets/speciesinfo/i/ impatiens-glandulifera/impatiens-glandulifera.pdf [2016 0109 ].

14. Yilmaz KU, Paydas S, Doganb Y, Kafkasb S. Genetic diversity analysis based on ISSR, RAPD and SSR among Turkish Apricot Germplasms in Iran Caucasian eco-geographical group. Sci Hortic. 2012; 138: 138-43.

15. Janssens SB, Geuten K, Yuan YM, Song Y, Küpfer P, Smets E. Phylogenetics of Impatiens and Hydrocera (Balsaminaceae) using chloroplast atpB-rbcL spacer sequences. Syst Bot. 2006; 31: 171-80.

16. Janssens SB, Knox EB, Huysmans S, Smets EF, Merckx VSFT. Rapid radiation of Impatiens (Balsaminaceae) during Pliocene and Pleistocene: Result of a global climate change. Mol Phylogenet Evol. 2009; 52: 806-24.

17. Kupcinskiene E, Zybartaite L, Janulioniene R, Zukauskiene J, Paulauskas A. Molecular diversity of small balsam populations in relation to site characteristics. Cent Eur J Biol. 2013; 8(10): 1048-61.

18. Kupcinskiene E, Zybartaite L, Paulauskas A. Comparison of genetic diversity of three Impatiens species from Central Europe and Baltic region. Zemdirbyste=Agriculture. 2015; 102(1): 87-94.

19. Nei M. Estimation of average heterozygosity and genetic distance from a small number of individuals. Genetics. 1978; 89(3): 583-90.

20. Nybom H, Weising K, Rotter B. DNA fingerprinting in botany: past, present, future. Investigative Genetics. 2014; 5: 1.

21. Patamsytė J, Čèsnienè T, Naugžemys D, Kleizaitè V, Vaitkūnienė V, Rančelis V, Žvingila D.
Assessment of genetic diversity of Bunias orientalis revealed by RAPD and ISSR markers. Zemdirbyste=Agriculture. 2011; 98(3): 293-300.

22. Skalova H, Moravcova L, Pyšek P. Germination dynamics and seedling frost resistance of invasive and native Impatiens species local climatic conditions. Perspect Plant Ecol Evol Syst. 2011; 13(3): 173-80.

23. Tanner R. Datasheets: Impatiens parviflora (small balsam) [Internet]. 2008. CAB Europe - UK, Bakeham Lane, Egham, Surrey TW20 9TY, UK. Available from: http://www. cabi.org/isc/datasheet/28768 [2016-01-16].

24. Vervoort A, Jacquemart AL. Habitat overlap of the invasive Impatiens parviflora DC with its native congener I. noli-tangere L. Phytocoenologia. 2012; 42(3-4): 249-57.

25. Vyšniauskienė R, Rančelienè V, Patamsytė J, Žvingila D. High genetic differention among wild populations of alien Medicago sativa species in Lithuania. Cent Eur J Biol. 2013; 8(5): 480-91.

26. Vyšniauskienė R, Rančelienė V, Žvingila D, Patamsytė J. Genetic diversity of invasive alien species Lupinus polyphyllus populations in Lithuania. Zemdirbyste=Agriculture. 2011; 98(4): 383-90.

27. Williams JGK, Kubelik AR, Livak KJ, Rafalski JA, Tingey SV. DNA polymorphisms amplified by arbitrary primers are useful as genetic markers. Nucleic Acids Research. 1990; 18(22): 6531-5.

28. Zybartaite L, Zukauskiene J, Jodinskiene M, Janssens SB, Paulauskas A, Kupcinskiene E. RAPD analysis of genetic diversity among Lithuanian populations of Impatiens glandulifera. Zemdirbyste=Agriculture. 2011; 98(4): 391-8. 
Edita Ramoniené, Lina Jociené, Algimantas Paulauskas, Eugenija Kupčinskienė

EUROPOS Impatiens RŪŠIŲ SKIRTUMAI PAGAL APPD IR PKSI ŽYMENIS

\section{Santrauka}

Tyrimų tikslas yra palyginti pagal atsitiktinai pagausintos polimorfinès DNR (APPD) ir paprastųjų kartotinių sekų intarpų (PKSI) žymenis tris Europos Impatiens rūšis, kurios surinktos skirtingose geografinèse zonose. Tai aktualu, nes trūksta informacijos, kaip visos trys Impatiens rūšys gali būti palyginamos platesnèje geografinèje teritorijoje. Iš viso ištirtos kiekvienos rūšies - Impatiens noli-tangere, I. parviflora ir I. glandulifera - 8 populiacijos iš dviejų šalių (Lietuvos ir Čekijos Respublikos). APPD ir PKSI metodai pasirinkti atsižvelgiant ị duomenų trūkumą vertinant bendras molekulines Impatiens rūšių savybes. Buvo taikomi 8 APPD ir 5 PKSI žymenys. Lyginant polimorfizmo procento vidurkius, pagal APPD žymenis artimiausios buvo I. noli-tangere ir I. parviflora rūšys (atitinkamai $P \%=13,9 \%$ ir $P \%=17,3 \%$ ), o pagal PKSI duomenis - I. parviflora ir I. glandulifera (atitinkamai $P \%=26,5 \%$ ir $P \%=22,0 \%$ ). I. parviflora pasižymèjo didžiausia genetine diferenciacija pagal APPD lokusus $\left(G_{S T}=0,81\right)$ ir I. glandulifera - pagal PKSI žymenis $\left(G_{S T}=0,73\right)$. Atsižvelgiant $\mathfrak{i}$ genetinès diferenciacijos rezultatus, panašiausios rūšys pagal APPD duomenis yra I. noli-tangere ir I. parviflora, o pagal PKSI žymenis - invazinès sprigès rūšys. Genetinių atstumų palyginimas tarp suporuotų rūšių populiacijų rodo reikšmingą koreliaciją tarp I. noli-tangere ir I. parviflora $(r=0,79 ; p<0,05)$ bei $I$. parviflora ir I. glandulifera $(r=0,76 ; p<0,05)$ pagal APPD lokusus, taip pat I. parviflora ir I. glandulifera $(r=0,89 ; p<0,05)$ pagal PKSI žymenis. UPGMA dendrogramos atskleidè, kad panašiausios rūšys yra I. noli-tangere ir I. parviflora pagal APPD duomenis, I. parviflora ir I. glandulifera pagal PKSI žymenis, o I. noli-tangere ir I. glandulifera labiausiai skiriasi pagal minètus molekulinių žymenų rodiklius.

Raktažodžiai: Balsaminaceae, invazinès rūšys, genetinè ịvairové, sprigé 